\title{
IDENTIFICATION OF AN ESSENTIAL TRYPTOPHANYL RESIDUE IN THE PRIMARY STRUCTURE OF GLUCOAMYLASE G2 FROM ASPERGILLUS NIGER
}

\author{
by \\ ANTHONY J. CLARKE ${ }^{i \prime}$ and BIRTE SVENSSON ${ }^{21}$ \\ Department of Chemistry, Carlsberg Laboratory, \\ Gamle Carlsberg Vej 10, DK-2500 Copenhagen Valby \\ ${ }^{17}$ Present address: Division of Biological Sciences, \\ National Research Council of Canada, Ottawa, Ontario K1A 0R6 \\ ${ }^{2}$ To whom all correspondence should be addressed
}

Keywords: N-Bromosuccinimide, acarbose, affinity chromatography, acarbose-Sepharose, reverse phase HPLC, UV-spectroscopy, Taka-amylase A

Enzymatically active, $\mathrm{N}$-bromosuccinimide oxidized glucoamylase G2 (EC 3.2.1.3) was prepared in the presence of the inhibitor acarbose and inactive, oxidized G2 with capacity to bind substrate was prepared in the presence of maltose. Four out of 15 tryptophanyl residues were oxidized in the first derivative and five in the latter. In order to identify this fifth and essential residue, tryptic fragments of the two G2 derivatives were isolated. The peptide fragment from the inactive G2 derivative containing the additional oxindolealanine residue was located in HPLC chromatograms by UV-absorption measurements. Normal and second derivative UV-spectra, amino acid composition and $\mathrm{NH}_{2}$-terminal sequence of the isolated fragment led to identification of $\operatorname{Trp}(120)$ as a residue essential for activity. A short homologous amino acid sequence precedes both this $\operatorname{Trp}(120)$ and the $\operatorname{Trp}(83)$ which is involved in substrate binding in Taka-amylase A (J. Biochem. 95, 697-702 (1984)).

\section{INTRODUCTION}

With several carbohydrases, X-ray crystallography, UV-difference spectroscopy, NMR and fluorescence spectroscopy show that tryptophanyl residues are involved in substrate binding $(1-4,12,13,15,16,22)$. Glucoamylase (EC 3.2.1.3) which catalyzes the release of D-glucose from the non-reducing ends of starch and related oligo- and polysaccharides, has a tryptophanyl residue in subsite $l$ of the substrate binding region $(11,23)$. Recently, a second essential tryptophan was found in glucoamylase from
Aspergillus niger and these two residues apparently play different roles in the action of the enzyme (9).

In the present study we have identified a tryptophanyl residue required to maintain the catalytic activity as $\operatorname{Trp}(120)$ in the primary structure of glucoamylase $\mathrm{G} 2$ from $\mathrm{A}$. niger. G2 differs from $\mathrm{G} 1$ by lacking a $\mathrm{COOH}$-terminal region of approx. 100 amino acid residues, but the two forms have essentially the same activity on soluble substrates (31). The amino acid sequence of the enzyme $(5,6,30)$ near the

Abbreviations: $A H=$ aminohexyl; $G 1$ and $G 2=$ the larger and the smaller of the two forms of glucoamylase from A. niger (31); HPLC = high pressure liquid chromatography; NBS = N-bromosuccinimide; TFA = trifluoroacetic acid: Tris $=2$-amino-2(hydroxymethyl)-1,3-propandiol . 
essential residue resembles that near a tryptophanyl residue of Taka-amylase A, proposed to interact with substrate in the active site cleft of this $\alpha$-amylase $(20,33)$.

\section{MATERIALS}

A commercial preparation of Aspergillus niger glucoamylase (AMG 200L) was generously supplied by Novo Industries, Bagsvaerd, Denmark and the G2 form of the enzyme was purified to homogeneity as previously described (31). Sigma Chemical Co., St. Louis, MO, supplied cyanogen bromide while both iodoacetic acid and $\mathrm{N}$-bromosuccinimide were purchased from Fluka, Buchs, Switzerland. N-Acetyl-Ltryptophan amide was obtained from Bachem, Feinkemikalien AG, Bubendorf, Switzerland. AH-Sepharose 4B was a product of Pharmacia Fine Chemicals, Uppsala, Sweden. Bio-Gel P. 100 was from Bio-Rad, Richmond, CA. Substrates and inhibitors were obtained as earlier reported (9) as were reagents and solvents for preparation, isolation and sequencing of peptide fragments $(29,30)$.

\section{METHODS}

\subsection{Chemical modification with $\mathbf{N}$ - bromosuccinimide}

The modification of $\mathrm{G} 2$ in the presence of specific ligands was performed essentially as previously described $(9,27)$. Aliquots $(200-400$ $\mu \mathrm{l})$ of $10 \mathrm{mM}-\mathrm{NBS}$ were sequentially added to a Millipore-filtered solution $(50 \mathrm{ml})$ of $\mathrm{G} 2(15 \mu \mathrm{M})$ containing either acarbose $(0.15 \mathrm{mM})$ or maltose $(56 \mathrm{~mm})$ in $50 \mathrm{~mm}$-sodium acetate $\mathrm{pH} 4.3$.

\subsection{Affinity chromatography on acarbose- Sepharose}

Acarbose was activated with $\mathrm{CNBr}$ at $\mathrm{pH} 10.5$ and coupled to AH-Sepharose in $0.2 \mathrm{M}$-sodium borate $\mathrm{pH} 8.7$ overnight at $4{ }^{\circ} \mathrm{C}$. For affinity chromatography, $\mathrm{G} 2$ derivatives were applied to a column of acarbose-Sepharose in $0.1 \mathrm{M}$-sodium acetate, $0.5 \mathrm{M}$-sodium chloride $\mathrm{pH} 4.3$. Elution of bound enzyme was achieved with 1.7 $\mathrm{M}$-Tris- $\mathrm{HCl} \mathrm{pH} \mathrm{7.6.} \mathrm{The} \mathrm{eluate} \mathrm{was} \mathrm{immediately}$ dialyzed against $0.05 \mathrm{M}$-sodium acetate $\mathrm{pH} 4.3$.

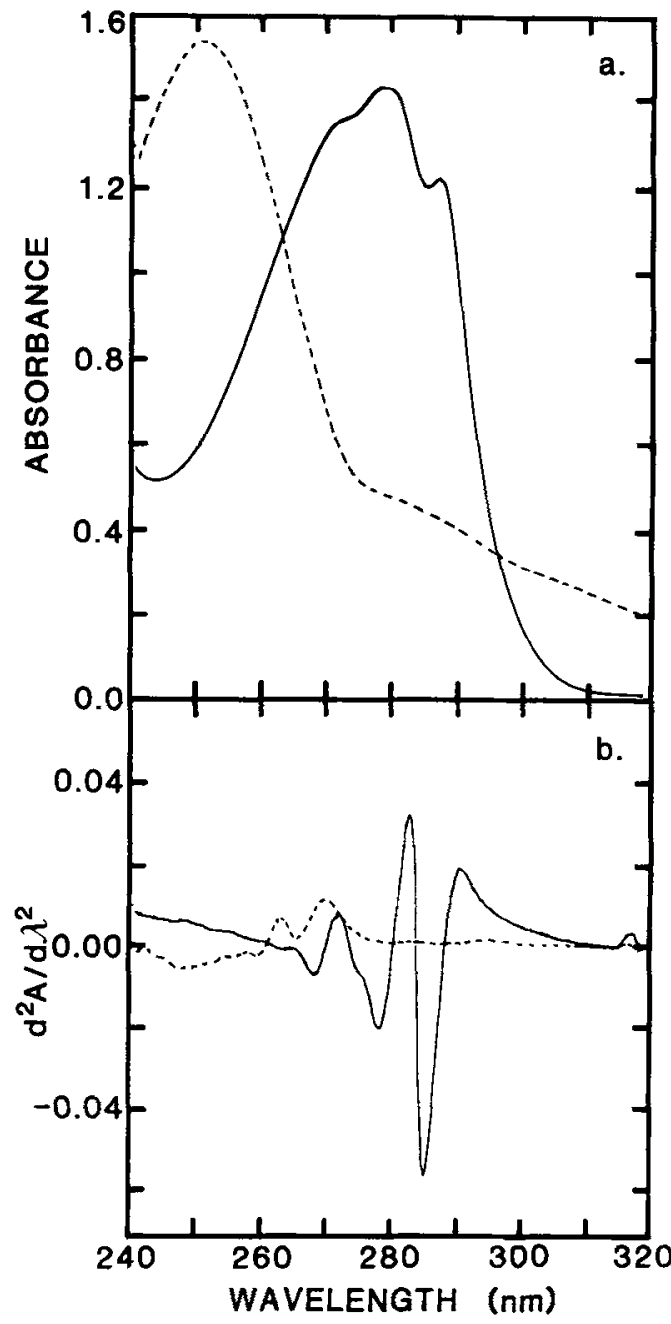

Figure I. Normal (a) and second-derivative (b) UV-absorption spectra of $\mathrm{N}$-acetyl-tryptophan amide and $\mathrm{N}$-acetyl-oxindolealanine amide. - - $\mathrm{N}$-acetyl-tryptophan amide $(0.26 \mathrm{~mm})$ in $50 \mathrm{~mm}$-sodium acetate $\mathrm{pH} 4$.3. --..-, $\mathrm{N}$-acetyl-oxindolealanine amide $(0.25$ $\mathrm{mM}$ ) in $50 \mathrm{~mm}$-sodium acetate $\mathrm{pH} \mathrm{4.3.} \mathrm{The} \mathrm{latter}$ spectra were recorded following five minutes of incubation with NBS.

\subsection{Preparation and isolation of tryptic fragments}

The $\mathrm{G} 2$ derivatives were reduced and carboxymethylated essentially as described (31) at a protein concentration of $30 \mathrm{mg} \times \mathrm{ml}^{-1}$ and a two-fold molar excess of iodoacetate over sulfhydryls. Carboxymethyl-G2 derivatives (5.8 $\left.\mathrm{mg} \times \mathrm{ml}^{-1}\right)$ were digested at $37^{\circ} \mathrm{C}$ with trypsin $(0.1$ 
$\mathrm{mg} \times \mathrm{ml}^{-1}$ ) for 4 hours (29). Tryptic peptides (40 $\mathrm{mg}$ ) were separated by gel filtration on Bio-Gel $\mathrm{P}-100(1.5 \times 90 \mathrm{~cm})$ in $0.2 \mathrm{M}$-ammonium bicarbicarbonate $\mathrm{pH} 7.8$ and pooled as earlier published (29). These peptide pools were further fractionated by HPLC using a Waters liquid chromatography system and a Wide-Pore $\mathrm{C}_{18}$ column from J.T. Baker Research Products eluted with a linear gradient from $0.1 \%$ TFA to $0.1 \%$ TFA in $40 \% 1$-propanol $(19,29)$.

\subsection{UV-Spectroscopy}

The tryptophan content of peptides was determined spectrophotometrically by the method of SERVILLo et al. (26) employing a Varian 2200 recording spectrophotometer. Figure 1 shows the normal and the 2 nd derivative spectra of both $\mathrm{N}$-acetyl-tryptophan amide and $\mathrm{N}$-acetyloxindolealanine amide (generated by NBS in situ). It is seen that abolition of the 2 nd derivative signal in the region from $275 \mathrm{~nm}$ to $320 \mathrm{~nm}$ upon NBS oxidation permits the estimation of the content of tryptophan in the presence of oxindolealanine.

\subsection{Analytical procedures}

Concentrations of $\mathrm{G} 2$ were determined spectrophotometrically employing the $\varepsilon_{280}$ value of $1.09 \times 10^{5} \mathrm{M}^{-1} \times \mathrm{cm}^{-1}(9)$. Enzymatic activity was determined with maltose $(15 \mathrm{mM})$ as substrate (31). Amino acid analysis of peptides was performed after acid hydrolysis for 24 hours at 110 ${ }^{\circ} \mathrm{C}$ with a Durrum D-500 amino acid analyzer and peptides were sequenced in the presence of Polybrene (17) using a Beckman Sequencer $890 \mathrm{C}$ as earlier described $(14,28)$. Fluorescence spectra were obtained at $25^{\circ} \mathrm{C}$ employing an Aminco SPF500 spectrofluorometer.

\section{RESULTS}

The active and the inactive, oxidized G2 preparations, obtained with acarbose and maltose protection, respectively (section 3.1 ), contained approx. $10 \%$ of non-ligand binding enzyme molecules which were eliminated by affinity chromatography on acarbose-Sepharose (section 3.2). The tryptic fragments of $\mathrm{G} 2$ deriv- atives were obtained and fractionated as described (section 3.3). Peptide fragments, eluting from the Bio-Gel P-100 at a volume between 125 $\mathrm{ml}$ and $140 \mathrm{ml}$, were separated in analytical scale by reverse phase HPLC with monitoring at 280 , 250 , and $220 \mathrm{~nm}$ and gave rise to the chromatograms shown in Figure $2 a$ and $b$. A large peak indicated by arrows represented a major difference in the UV-absorption properties between fragments derived from the active and inactive G2 derivative, respectively. Both the unmodified and the modified peptide eluted at the same position from the HPLC column. Material corresponding to this peak was isolated on a larger scale from the two G2 derivatives and rechromatographed over the Wide-Pore column using a 60 minute linear gradient from 8 to $16 \%$ 1-propanol in $0.1 \%$ TFA.

The identification of the isolated fragments was established by amino acid analysis and $\mathrm{NH}_{2}$-terminal sequencing (Table I). These results are consistent with the fragment:

Phe-Asn-Val-Asp-Glu-Thr-Ala-Tyr-Thr-Gly-Ser-Trp
109

Table I. Amino acid composition of the Phe(109)Trp(120)-peptide from oxidized glucoamylase G2

\begin{tabular}{|c|c|c|}
\hline G2 derivative & Active & Inactive \\
\hline Amino acid & \multicolumn{2}{|c|}{ Residues/fragment ${ }^{\text {al }}$} \\
\hline Aspartic acid & 1.6 & 1.8 \\
\hline Threonine & 1.5 & 1.7 \\
\hline Serine & 1.1 & 1.3 \\
\hline Glutamic acid & 0.9 & 1.1 \\
\hline Glycine & 0.9 & 1.3 \\
\hline Alanine & 1.0 & 1.0 \\
\hline Valine & 0.8 & 0.7 \\
\hline Tyrosine & 0.8 & 0.8 \\
\hline Phenylalanine & 0.7 & 0.8 \\
\hline Tryptophan" & 0.9 & 0.0 \\
\hline Oxindolealanine & - & 1.1 \\
\hline $\mathrm{NH}_{2}-$ Terminal yield $(\%)^{\mathrm{d}}$ & 70 & 45 \\
\hline \multicolumn{3}{|c|}{$\begin{array}{l}\text { bstimated from second-derivative UV-absorbance } \\
\text { assuming } \mathrm{Tyr}_{\mathrm{r}}=1.0\end{array}$} \\
\hline \multicolumn{3}{|c|}{$\begin{array}{l}\text { Estimated from UV-absorbance assuming } \varepsilon_{2 s U}= \\
6.6 \times 10^{3} \mathrm{M}^{-1} \times \mathrm{cm}^{-1} \text {. }\end{array}$} \\
\hline \multicolumn{3}{|c|}{$\begin{array}{l}\text { The yield of phenylthiohydantoin-Phe in the first } \\
\text { step of the automated sequencing based on a peptide } \\
\text { content determined from amino acid analysis. }\end{array}$} \\
\hline
\end{tabular}




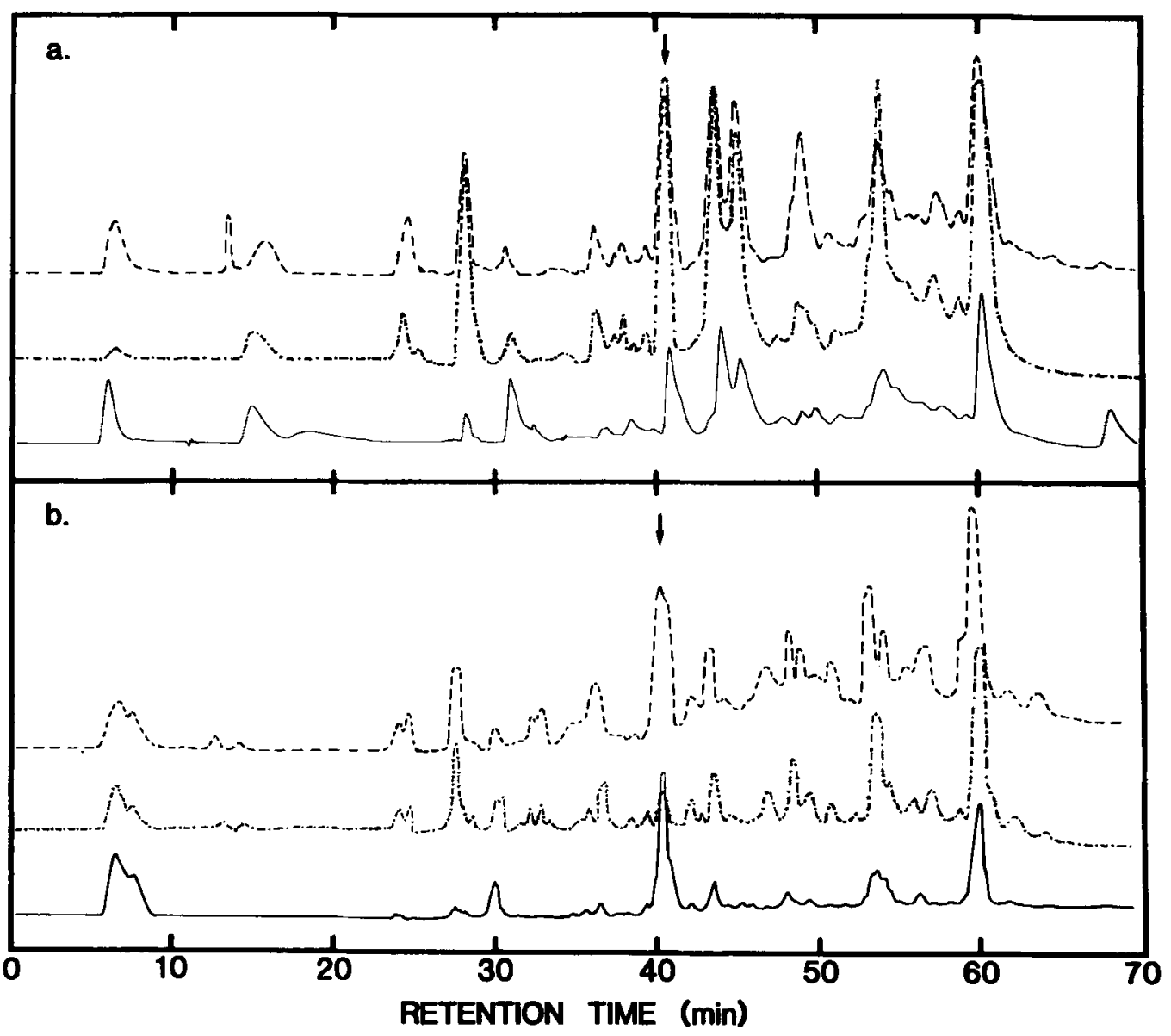

Figure 2. HPLC elution profiles of tryptic fragments from active G2 with four (a) and inactive $G 2$ with five (b) oxidized tryptophans. Approx. $0.4 \mathrm{mg}$ of a mixture of peptides, eluted from a Bio-Gel P-100 column as described in section 4 , was applied in $0.1 \%$ TFA to a Wide-Pore $C_{18}$ column in each of three separate runs. Elution was accomplished employing an 80 minute linear gradient of $0-40 \%$ l-propanol in $0.1 \%$ TFA at a flow rate of $0.5 \mathrm{ml} \times \mathrm{min}^{-1}$. The eluant was monitored at $220 \mathrm{~nm}(----), 250 \mathrm{~nm}(-)$ or $280 \mathrm{~nm} \mathrm{(.} \mathrm{-} \mathrm{.} \mathrm{-).}$ The scale for $A_{220}$ is 10 times greater than that of either $A_{250}$ or $A_{280}$. The arrows indicate the peak representing a major change in the $A_{280} / A_{250}$ ratio between the profiles in $a$ and $b$.

in the amino acid sequence of glucoamylase (5, 30). The UV-absorption of the isolated peptide (Figure 3) confirmed the presence of an intact tryptophan in the fragment from $\mathrm{G} 2$ oxidized in the presence of acarbose, while in contrast the fragment from the inactive $\mathrm{G} 2$ derivative exhibited oxindolealanine UV-absorption. Minor components from digests of both inactive and active $G 2$ derivatives comprising residues Phe(109)-Arg(122) and Phe(109)-Arg(125) (30) were also isolated and possessed similar UV. spectra to those above (results not shown). Thus, the oxidation of the $\operatorname{Trp}(120)$ seemed to be accompanied by the loss of maltose-hydrolyzing capacity of glucoamylase.

The intrinsic fluorescence of the G2 complexes with the inhibitor acarbose (a pseudotetrasaccharide), with starch or with the small substrates maltose and maltotriose are shown in Figure 4. Acarbose induced a red shift and an increase of the relative fluorescence of $\mathrm{G} 2$, whereas all the substrates, i.e. starch, maltose and maltotriose, partially quenched the fluorescence and induced a blue shift of the maximum. 


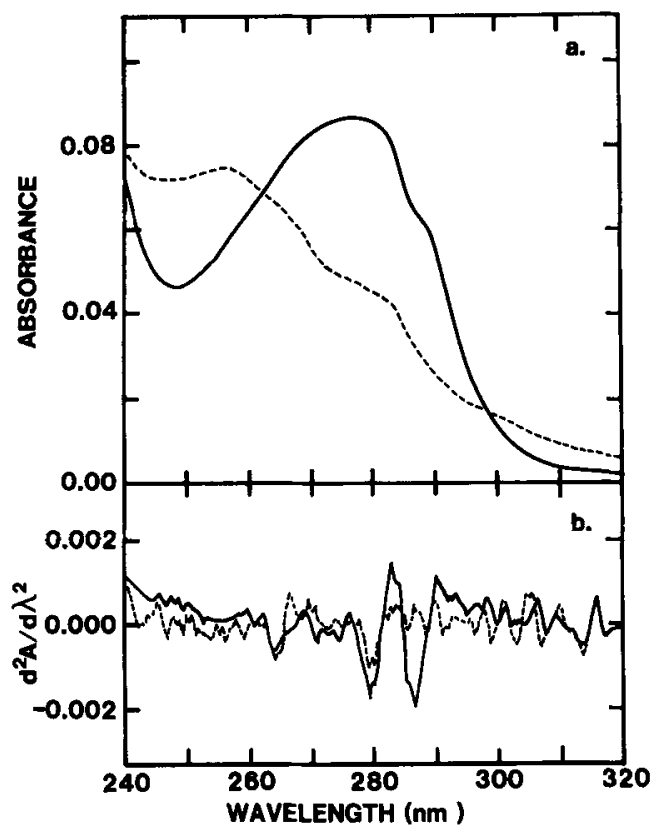

Figure 3. Normal (a) and second-derivative (b) UV-absorption spectra of the isolated Phe(109)-Trp(120)peptide from active, oxidized $\mathrm{G} 2(16.7 \mu \mathrm{M}, \longrightarrow)$ and inactive, oxidized G2 $(14,5 \mu \mathrm{M},-----)$ in $100 \mathrm{~mm}$-ammonium bicarbonate $\mathrm{pH} 7.8$.

\section{DISCUSSION}

It has previously been shown that $\mathrm{N}$-bromosuccinimide oxidation of glucoamylases $\mathrm{Gl}$ and $\mathrm{G} 2$ from $\mathrm{A}$. niger led to derivatives that were devoid of enzymatic activity. The presence of the inhibitor acarbose afforded protection of both the enzymatic activity and two tryptophanyl residues. All other ligands examined only protected a single tryptophanyl residue, thought to be located in subsite 1 of the substrate binding region $(9,11)$, and in these cases the resulting derivatives were catalytically inactive (9). Thus, the tryptophan essential for hydrolase activity is oxidized in the latter derivatives and three tryptic peptides $(29,30)$ containing the oxidized tryptophan: Phe(109)-Trp(120), Phe(109)-Arg (122), and Phe(109)-Arg(125) were isolated. The first one was predominant presumably as a consequence of both a slow hydrolysis of the $\operatorname{Arg}(122)-\operatorname{Pro}(123)$ peptide bond and a contamination of the employed commercial trypsin preparation with chymotrypsin. The UV-ab-

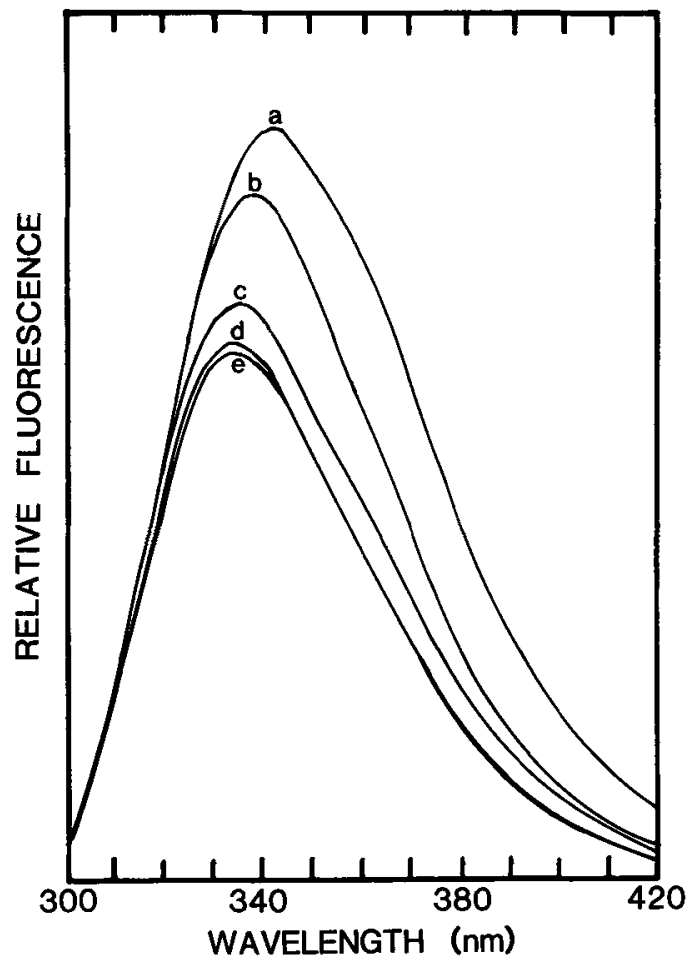

Figure 4. Fluorescence emission spectra of native glucoamylase $\mathrm{G} 2$ in the absence (b) and presence of ligands. Enzyme $(3.7 \mu \mathrm{M})$ in $50 \mathrm{~mm}$-sodium acetate pH 5.0 at $25^{\circ} \mathrm{C}$ in the presence of $0.14 \mathrm{mM}$-acarbose (a), $0.25 \%$ soluble starch (c), 15 mM-maltose (d) or $15 \mathrm{~mm}$-maltotriose (e). Excitation wavelength was fixed at $280 \mathrm{~nm}$.

sorption properties of the different isolated peptides, however, clearly confirmed the complete oxidation of Trp (120) by NBS in the presence of maltose and the protection of this residue in the G2-acarbose complex. Since no major difference was observed for other tryptophanyl residues when comparing the Bio-Gel P-100 and the HPLC chromatograms of tryptic fragments from the active and inactive $\mathrm{G} 2$ derivatives, the $\operatorname{Trp}(120)$ was concluded to be essential for maintaining the catalytic activity. However, its precise role in the function of glucoamylase remains unclear. Thus, this residue was not protected from oxidation by small substrates like maltose and maltotriose, but seemed on the contrary to be even more readily oxidized in 
Glucoamylase from Aspergillus niger $(5,30)$ :

-Pro-Lys-Phe-Asn-Val-Asp-Glu-Thr-Ala-Tyr-Thr-Gly-Ser-Trp-Gly-Arg-Pro-

Taka-amylase A from Aspergillus oryzae (33):

-Pro-Gln-Asp-Cys-Ala-Tyr-Gly-Asp-Ala-Tyr-Thr-Gly-Tyr-Trp-Glu-Thr-Asp-

Figure 5. Sequence alignment guided by the essential $\operatorname{Trp}(120)$ of glucoamylase and the $\operatorname{Trp}(83)$ of Takaamylase $A$, involved in substrate binding (20).

their presence, as judged from the loss of activity (9). Furthermore, SAVEL'EV and FIRSOv have recently reported that the rate of NBS inactivation of glucoamylase from Aspergillus awamori is significantly reduced by maltotetraose, but not by smaller substrates, and this suggests a tryptophan to be located in subsite 4 of this glucoamylase (25). Similarly, in our studies of A. niger glucoamylase starch afforded some protection against oxidation, although only acarbose completely prevented the inactivation under the actual experimental conditions (9). Acarbose and starch thus seem to interact in different ways with $G 2$ which was consistent with the clearly different changes of the G2 intrinsic fluorescence spectra induced by each of these compounds. In summary, the $\operatorname{Trp}(120)$ appears to be exposed in enzyme-substrate complexes comprising the binding affinity subsites 1,2 , and $3(9$, 11), partially protected in complexes with longer substrates and effectively protected only in the inactive enzyme-acarbose complex (9). Since the hydrolysis occurs between sugar residues number 1 and 2 from the non-reducing end of the substrate (11), the experiments with glucoamylase from $\mathrm{A}$. niger also indicate that the essential Trp(120) is probably located at some distance from the catalytic site. It might, however, be involved in maintaining the structural integrity needed for productive substrate binding and catalysis to occur. Thus, the catalytically inactive $\mathrm{G} 2$, prepared by oxidation in the presence of the small substrate maltose, still does bind substrate (9) and an analogous situation has been described in structural detail for lysozyme after oxidation of $\operatorname{Trp}(62)$ to oxindolealanine. In this case a conformational change caused oxindolealanine(62) to block a part of the active site cleft and as a consequence ligands would bind but non-productively (4).

Although there is no general sequence homology between this glucoamylase and known $\alpha$ amylases $(10,18,24,32,33)$, it was observed that a short stretch of polypeptide chain, preceding $\operatorname{Trp}(120)$ in glucoamylase and the $\operatorname{Trp}(83)$ in the Taka-amylase A (20) (from A. oryzae) was identical (Figure 5). The $\operatorname{Trp}(83)$ is located in the active site cleft of the three-dimensional structure of Taka-amylase A and model fitting studies with amylose have recently proposed that $\operatorname{Trp}(83)$ participates in binding of this substrate (20). Although this tryptophan is not conserved throughout the $\alpha$-amylases, it is present in the two fungal enzymes, Taka-amylase $\mathrm{A}$ and glucoamylase, and one might speculate about similarities in their structures. In fact, preliminary secondary structure predictions a.m. CHOU and FASMAN (8), indicate that glucoamylase might fold in two domains with a $\mathrm{COOH}$-terminal region dominated by $\beta$-structure and a large $\mathrm{NH}_{2}$-terminal domain of alternating $\alpha$ - and $\beta$-structure (B. SvENSSON, unpublished data). Thus the exo- $\alpha$-glucanase, glucoamylase, perhaps belongs to the class of enzymes having an $\alpha / \beta$-barrel supersecondary structure (21), like the endo- $\alpha$-glucanases Taka-amylase A (20) and porcine pancreas $\alpha$-amylase (7). It is of great interest to test this hypothesis by using the coordinates obtained from X-ray crystallography of the $\alpha$-amylases to guide the folding of the polypeptide chain of glucoamylase. 


\section{ACKNOWLEDGEMENTS}

We are grateful to Professor Martin OTte. SEN for encouragement during this work and critical revision of the manuscript. Mss EDITH FLOISTRUP and SIDSEL EHLERS are thanked for expert technical assistance. Dr. IB SVENDSEN and Mss Bodil CORNELIUSSEN, LONE SøREN. SEN and PIA BREDDAM are acknowledged for peptide $\mathrm{NH}_{2}$-terminal sequencing and amino acid analyses. Drs. E. TRUSCHEIT and D. SCHMIDT, Bayer AG, are thanked for the generous gift of acarbose and Professor D.V. WETT. STEIN, the Department of Physiology, Carisberg Laboratory, and Dr. L. MUNCK, the Department of Biotechnology, Carlsberg Research Laboratories, for the use of the Varian 2200 recording spectrophotometer and the Aminco SPF500 spectrofluorometer, respectively.

\section{REFERENCES}

1. BACHMEYER, $\mathrm{H}$ : Effect of tryptophan modification on the activity of bacterial and viral neuraminidase. FEBS Lett. 23, 217-219 (1972)

2. Barker, S.A., C.J. Gray \& M.E. Jolley: Photooxidation of glucoamylase I from Aspergillus niger. Biochem. Biophys. Res. Comm. 45, 654-661 (1971)

3. Be.dDELL. C.R. C.C.F. BLAKE \& S.J. OATLEY: An $X$-ray study of the structure and binding proporties of iodine-inactivated lysozyme. J. Mol. Biol. 97, 643-654 (1975)

4. Blake. C.C.F., R. Cassels, C.M. Dobson, F.M Poulsen, R.J.P. Williams \& K.S. Wilson: Structure and binding properties of hen lysozyme modified at tryptophan 62. J. Mol. Biol, 147, 73-95 (198!)

5. Boel, E., I. Huort, B. SvensSon, F. Norris, K.E. NORRIS \& N.P. FIIL: Glucoamylases $G 1$ and G2 from Aspergillus niger are synthesized from two different but closely related mRNAs. EMBO J. 3, 1097-1102 (1984)

6. Boel, E., M. Trier HANSEN, I. HJort, I. Høegh \& N.P. FIIL: Two different types of intervening sequences in the glucoamylase gene from Aspergillus niger. EMBO J. 3, I58I-I585 (1984)

7. Buisson, G., E. Dué, R. Haser \& F. Payan: Crystallographic structure of pig pancreas $\alpha$-amylase $(2.9 \dot{A}$ resolution). 8th international Biophysic Congress, Bristol (1984), abstract 112, p. 60.

8. Chou.P.Y. \& G.D. Fasman: Prediction of protein conformation. Biochemistry 13, 222-244 (1974)

9. Clarke, A.J. \& B. Svensson: The role of trypto- phanyl residues in the function of Aspergillus niger glucoamylase G1 and G2. Carlsberg Res. Commun. 49, 111-122 (1984)

10. Hagenbuchle, O, R. Bovey \& R.A. Young: Tissue-specific expression of mouse a-amylase genes: nucleotide sequence of isoenzyme mRNAs from pancreas and salivary gland. Cell 21, 179-187 (1980)

11. Hiromi, K., M. Ohnishi \& A. TANaKa: Subsite structure and ligand binding mechanism of glucoamylase. Mol. Cell. Biochem. 51, 79-95 (1983)

12. Imoto, T. L.N. Johnson, A.C.T. North, D.C. Phillips \& J.A. RupleY: Vertebrate lysozymes. Enzymes 3rd ed. 7, 665-868 (1972)

13. InokUChI, N., T. Takahashi, A. Yoshimoto \& M. IRIE: N-Bromosuccinimide oxidation of a glucoamylase from Aspergillus saitoi. J. Biochem. 91, 1661-1668 (1982)

14. Johansen. J.T., C. Overballe-Petersen, B MARTIN, V. HASEMANN \& I. SVENDSEN: The complete amino acid sequence of copper, zinc superoxide dismutase from Saccharomyces cerevisjae. Carlsberg Res. Commun. 44, 201-217 (1979)

15. JOLLEY, M.E. \& C.J.GRAY: Tryptophanyl and carboxylic acid residues in the active center of glucoamylase I from Aspergillus niger. Carbohyd. Res. 49, 361-370 (1976)

16. Kita, Y., M. Fukazawa, Y. NitTa \& T. WataNABE: Kinetic study on chemical modification of Taka-amylase A. I. Location and role of tryptophan residues $J$. Biochem. 92, 653-659 (1982)

17. Klapper. D.G., C.E. Wilde III \& J.D. CAPRA: Automated amino acid sequence of small peptides utilizing Polybrene. Anal. Biochem. 85, 126-131 (1978)

18. KLUH, I.: Amino acid sequence of hog pancreatic $\alpha$-amylase isoenzyme I. FEBS Lett. 136, 231-234 (1981)

19. Mahoney, W.C. \& M.A.HeRmodson: Separation of large denatured peptides by reverse phase high performance liquid chromatography. Trifluoroacetic acid as a peptide solvent. J. Biol. Chem. 255 , 11199-11203 (1980)

20. Matsuura, Y., M. Kusunoki, W. Harada \& M KAKUDO: Structure and possible catalytic residues of Taka-amylase A. J. Biochem. 95, 697-702 (1984)

21. MUIRHEAD, H.: Triose phosphate isomerase, pyruvate kinase and other $\alpha / \beta$-barrel enzymes. Trends Bioch. Sci. 8, 326-330 (1983)

22. NitTa, Y., T. Kunikata \& T. Watanabe: Difference spectroscopic study of the interaction between soybean $\beta$-amylase and substrate or substrate analogues. J. Biochem. 93, 1195-1201 (1983) 
23. OhNishi, M.,M.TANiguChI\& K. Hiromi: Kinetic discrimination of tryptophan residues of glucoamylase from Rhizopus niveus by fast chemical modification with $\mathrm{N}$-bromosuccinimide. Biochim. Biophys. Acta 744, 64-70 (1983)

24. RogerS, J.C. \& C. Milliman: Isolation and sequence analysis of a barley $\alpha$-amylase cDNA clone. J. Biol. Chem. 258, 8169-8174 (1983)

25. SAVEL'EV. A.N. \& L.M. Firsov: Effect of modification of some amino acid radicals on enzymatic activity of glucoamylase from Aspergillus awamori. Biokhimiya 48, 1311-1318 (1983)

26. Servillo, L., G. Colonna, C. Balestrieri, R. RAGONE\& G. IRACE: Simultaneous determination of tyrosine and tryptophan residues in proteins by second-derivative spectroscopy. Anal. Biochem. 126, 251-257 (1982)

27. SPANDE, T.F. \& B. WITKOP: Determination of the tryptophan content of proteins with $\mathrm{N}$-bromosuccinimide. Meth. Enzymol. XI, 498-506 (1967)

28. SvendSen, I., B. MARTin \& I. Jonassen: Characteristics of Hiproly barley III. Amino acid sequences of two lysine-rich proteins. Carlsberg Res. Commun. 45, 79-85 (1980)

29. SVEnsson. B.. K. LARSEN \& I. Svendsen: Amino

Accepted by: H. KLenOw, E. Lund and S.O. ANDERSEN acid sequence of tryptic fragments of glucoamylase G1 from Aspergillus niger. Carlsberg Res. Commun. 48, 517-527 (1983)

30. Svensson, B., K. LaRSEN, I. SvendSen \& E. Boel: The complete amino acid sequence of the glycoprotein, glucoamylase G1 from Aspergillus niger. Carlsberg Res. Commun. 48, 529-544 (1983)

31. Svensson, B., T.G. Pedersen, I. Svendsen, T. SAKAI \& M. OTTESEN: Characterization of two forms of glucoamylase from Aspergillus niger. Carlsberg Res. Commun. 47, 55-69 (1982)

32. TÄKKINEN, K., R.F. PetTersSon, N. Kalkinen, I. Palva, H. Söderlund \& L. KäÄriänen: Amino acid sequence of $a$-amylase from Bacillus amyloliquefaciens deduced from the nucleotide sequence of the cloned gene. J. Biol. Chem. 258, 1007-1013 (1983)

33. TODA. H., K. Kondo \& K. Narita: The complete amino acid sequence of Taka-amylase $A$. Proc. Japan Acad. 58, Ser. B, 208-212 (1982)

34. Truscheit, E., W. Frommer, B. Junge, L. MÜLLER, D.D. SCHMIDT \& W. WINGENDER: Chemie und Biochemie mikrobieller $\alpha$-Glucosidaseninhibitoren. Angew. Chem. 93, 738-755 (1981) 